\title{
Spectral Filtering of Photovoltaic Cells using Novel Bio-Filter: Silver Coated Hibiscus Extract using Butanol Solution
}

\author{
Emetere Moses E., Adeyemo Nehemiah
}

\begin{abstract}
The adaptability of the solar photovoltaic cell is huge but not without its peculiar challenges. It has been reported that the patronage of photovoltaic $(P V)$ in Africa is drastically dropping due to the dismal performance of $P V$ in the first year of purchase. In this research, the bio-filter was proffered as an external solution to improving the efficiency and longevity of $P V$ module. It was observed that the bio-filter improved the efficiency of the polycrystalline panel by $60 \%$. This means that a good percentage of the solar IR radiation can be reflected from this proposed bio-filter. This research further affirms the significance of plants as a veritable tool to protect the PV panel. Hence, this bio-filter is adjudged to be cost-effective (i.e. affordable), universal usability and eco-friendly in both the long and short term.
\end{abstract}

Keywords: Photovoltaic, bio-filter, spectral filtering. Solar energy, energy

\section{INTRODUCTION}

A solar cell is an electronic device made of materials with semiconductors that can convert solar irradiance into electricity [1-4]. This type of device is mostly made from solid-state materials that enhance the release or hopping of electron to generate electricity. Semiconductor materials are the materials used to manufacture the solar cells. When energy is available, they work as conductors and in other cases as insulators. Most solar cells are produced using silicon-based technology, as this is the most mature technology. Other materials are under active investigation, however, and in the long run may replace silicon. The solar cell works on the principle of photovoltaic effect i.e. the process of converting solar irradiance into electricity [5-7]. That is why most solar cells are rather referred to as photovoltaic cell. An individual solar cell output is relatively low. The grouping of several cells is referred to photovoltaic panel or module. A solar PV module typically consists of 36 series and parallel connected solar cells [8]. As additional components other than solar cells, a PV module will consist

Revised Manuscript Received on December 30, 2019.

* Correspondence Author

Emetere Moses E. *, Department of Physics, Covenant University Canaan land, P.M.B 1023, Ota, Nigeria. Department of Mechanical Engineering Science, University of Johannesburg, South Africa. emetere@yahoo.com

Adeyemo Nehemiah, Department of Physics, Covenant University Canaan land, P.M.B 1023, Ota, Nigeria.

(C) The Authors. Published by Blue Eyes Intelligence Engineering and Sciences Publication (BEIESP). This is an open access article under the CC BY-NC-ND license (http://creativecommons.org/licenses/by-nc-nd/4.0/) of several bypass diodes. The electrons gain more energy when sunlight strikes on the cell and thus jump to a higher energy level [9]. The electrons are now free to move, allowing free movement of the holes in the materials. The electrons flow is the current flow. Hence, the greater the electrons flow, the greater the electricity to be generated from the photovoltaic (PV) panel. Globally, the sales of PV have risen due to the current adoption of solar grid system that has increased energy generation to over $300 \mathrm{GW}$ [10]. The figure does not in anyway include the standalone users especially in Africa. However, it is observed that despite the slash in the purchasing price of $\mathrm{PV}$ in the African market, patronage have been incredibly low i.e. compared to its population and the long-standing energy crisis. It was observed that the cost of maintenance of the solar standalone installations is high due to the malfunctioning of the PV panels. By observation, the performance of the PV drops to about 50\% in the first year of purchase. Scientists have rightly diagnosed the problem to be the release of harmful solar infrared radiation on the PV panel [11-12]. This challenge is quite unique because out of about $324 \mathrm{Wm}-2$ solar radiations reaching the Earth in the upper atmosphere, $86 \mathrm{Wm}-2$ is infrared radiation [13]. The ground reflects $20 \mathrm{Wm}$-2and about $66 \mathrm{Wm}-2$ are available to hit the surface of the PV panel.

Based on the above, the solution to this problem may be either modifying the PV fabrication or fabricating external device that is attachable to the PV device. In this research, we concentrate on the external device, which to a large extent is affordable, universal and eco-friendly. In this research, the bio-filter was suggested as a green solution to the aforementioned research problem. The bio-filter is basically metallic coated plant extract. The plant extract was selected because it is found that plants leaf absorbs $20 \%$, reflects 50\% and transmits $30 \%$ of solar infrared radiation [14]. This makes it a very good candidate for the proposed bio-filter. The metallic coating is very important because it improve upon the optical or reflective of the plant extract. In this research, the bio-filter was tested on the monocrystalline and polycrystalline panel.

\section{MATERIALS AND METHOD}

The materials used for the experiment includes: monocrystalline panel (3watt), solarimeter, silver nitrate (Ag2NO3), polycrystalline panel (4 watt), methanol solution, ethanol solution, butanol solution, multimter, weighing balance, beaker and data logger. 
The biofilter was synthesized in the laboratory using hibiscus flower extract and silver nitrate. The hibiscus flower were gotten around the Ota environ, Nigeria. The flowers were divided into four parts. Each portion of the flower was grinded (using electronic blender) in $20 \mathrm{ml}$ of ethanol. After blending, extracts were filtered out and mixed with $1.84 \mathrm{~g} /$ mole of silver oxide (Ag2NO3) and then left for a day so that the silver compound can dissolve with the mixture. The filtrate was not heated to conserve the vital chemical components of the hibiscus flower (saturated hydrocarbons from 25 to 33 carbon atoms, esters, and carboxylic acids [15]). The two-polycrystalline PV panels (i.e. one panel sprayed with the biofilter and the second panel not sprayed) and four monocrystalline panels (i.e. two sprayed with the biofilter and the other two panels not sprayed) were connected to the data logger as shown in Figure 1.

The data logger was used to measure desired parameters such as radiation, current, voltage and power for two types of PV panels i.e. monocrystalline and polycrystalline [16]. A data logger records and saves all readings gotten from the PV panels in an SD card.

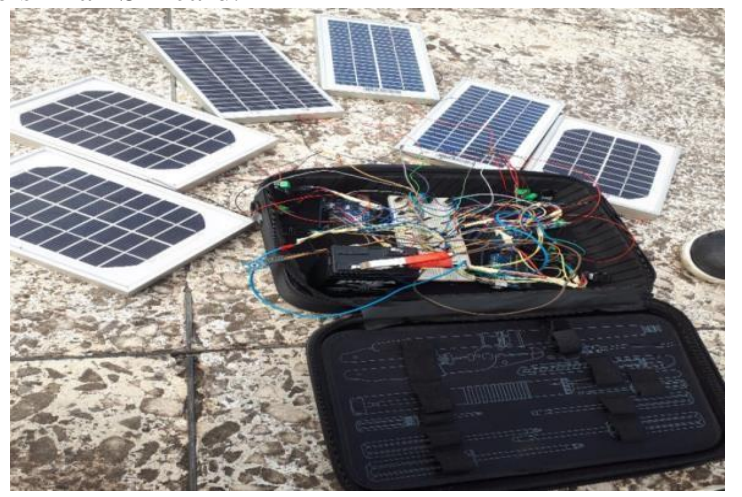

Figure 1: Experimental set-up for field measurement

\section{RESULTS AND DISCUSSION}

This journal uses double-blind review process, which means that both the reviewer (s) and author (s) identities concealed from the reviewers, and vice versa, throughout the review process. All submitted manuscripts are reviewed by three reviewers one from India and rest two from overseas. There should be proper comments of the reviewers for the purpose of acceptance/ rejection. There should be minimum 01 to 02 week time window for it.

\section{MATH}

The graph below (Figure 2) shows the UV radiation (w/m2) against time (sec) plot of the silver coated hibiscus extract in butanol solution for the monocrystalline panel. The UV over the period was at its peak between $2000-2800$ sec. It was found that the maximum radiation is measured as $30 \mathrm{~W} / \mathrm{m} 2$. From the graph it is noticed that were fluctuating radiations that gives insight on the solar pattern over the research area. The graph below (Figure 3) shows the voltage (V) against time (sec) plot of the silver coated hibiscus extract in butanol solution for the monocrystalline panel. From the graph it is observed that there were rise and fall of voltages at various time intervals. The blue legend shows the coated panel while the green legend shows the uncoated monocrystalline panel. The values of the coated and uncoated panels were found to be almost the same.
The graph below (Figure 4) shows the current (A) against time (sec) plot of the silver coated hibiscus extract in butanol solution for the monocrystalline panel. The blue legend shows the coated panel while the green legend shows the uncoated monocrystalline panel. It is observed that the current of the uncoated panel is slightly higher than the coated panel, it is also noticed that the graph is sinusoidal in nature.

The graph below (Figure 5) shows the power (W) against time (sec) plot of the silver coated hibiscus extract in butanol solution for the monocrystalline panel. The blue legend shows the coated panel while the green legend shows the uncoated monocrystalline panel. The power output in uncoated panel was found to be slightly higher than the coated panel.

The graph below (Figure 6) shows the UV radiation (w/m2) against time (sec) plot of the silver coated hibiscus extract in butanol solution for the polycrystalline panel. The UV graph over the period was with a maximum radiation of $64 \mathrm{w} / \mathrm{m} 2$.

The graph below (Figure 7) shows the voltage (V) against time (sec) plot of the silver coated hibiscus extract in butanol solution for the polycrystalline panel. The blue legend shows the coated panel while the green legend shows the uncoated polycrystalline panel. It was found that the voltage output in the coated panel was higher than the uncoated panel.

The graph below (Figure 8) shows the current (A) against time (sec) plot of the silver coated hibiscus extract in butanol solution for the polycrystalline panel. The current output was found to be at its lowest value for both coated and uncoated panel.

The graph below (Figure 9) shows the power (W) against time (sec) plot of the silver coated hibiscus extract in butanol solution for the polycrystalline panel. The blue legend shows the coated panel while the green legend shows the uncoated polycrystalline panel. It was observed that the power output in the coated panel was significantly higher than uncoated panel. This means that the bio-filter improved the efficiency of the panel by $60 \%$.

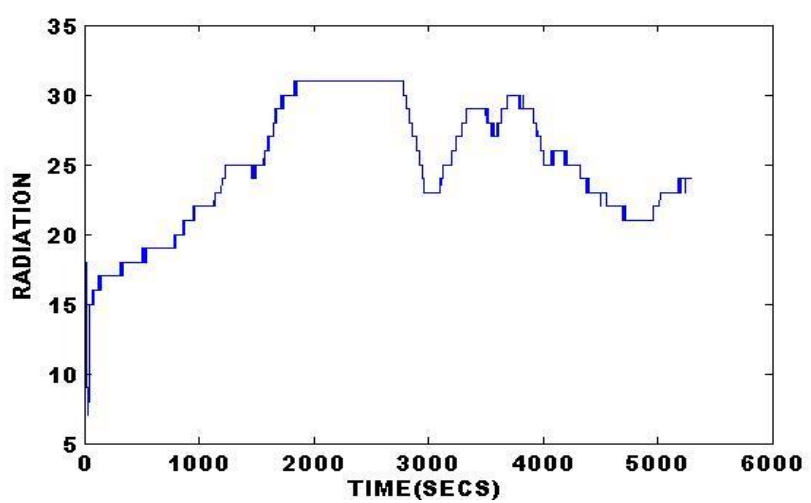

Figure 2: UV radiation(w/m $\left.{ }^{2}\right)$ against Time (sec) of Silver coated hibiscus extract in butanol solution for the monocrystalline panel 


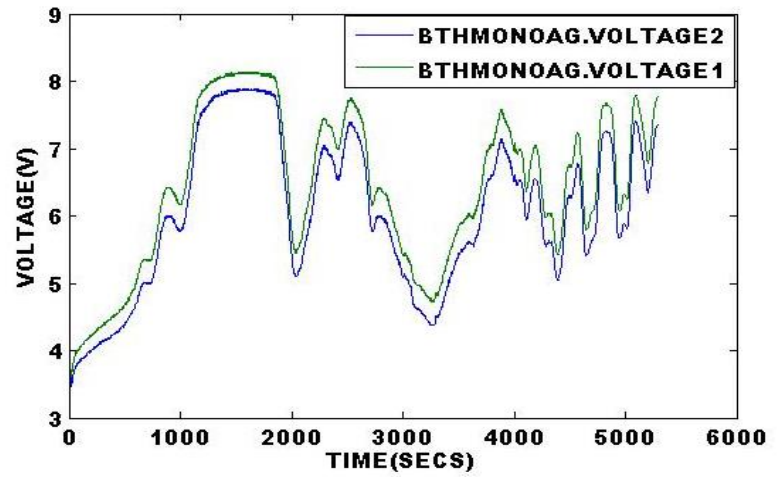

Figure 3: Voltage (V) against Time (Sec) of the Silver coated hibiscus extract in butanol solution for the monocrystalline panel.

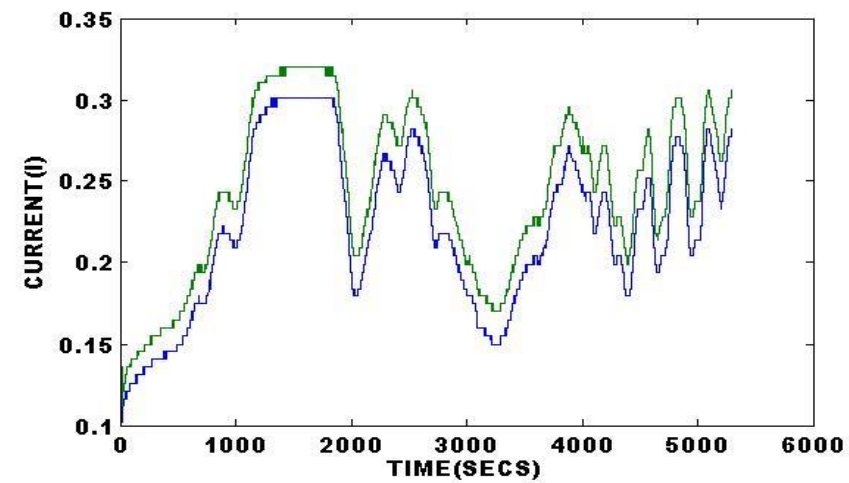

Figure 4: Current (A) against Time (Sec) of the Silver coated hibiscus extract in butanol solution for the monocrystalline panel.

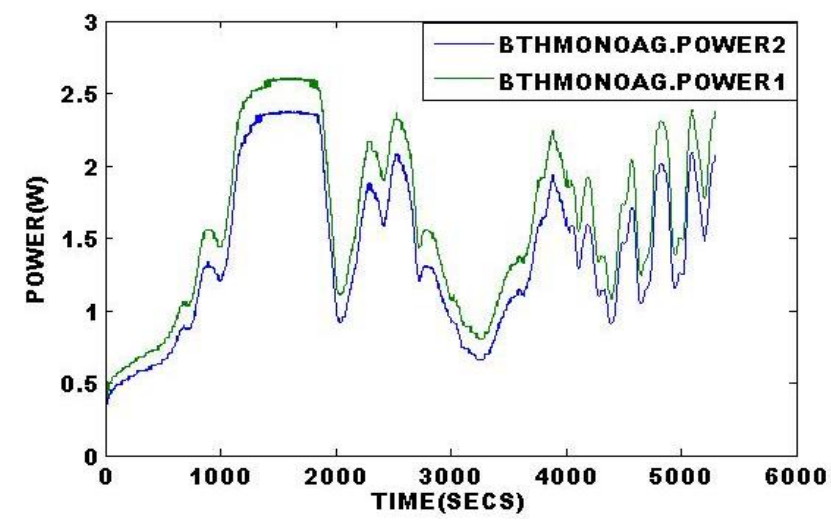

Figure 5: Power (W) against Time (Sec) of the Silver coated hibiscus extract in butanol solution for the monocrystalline panel.

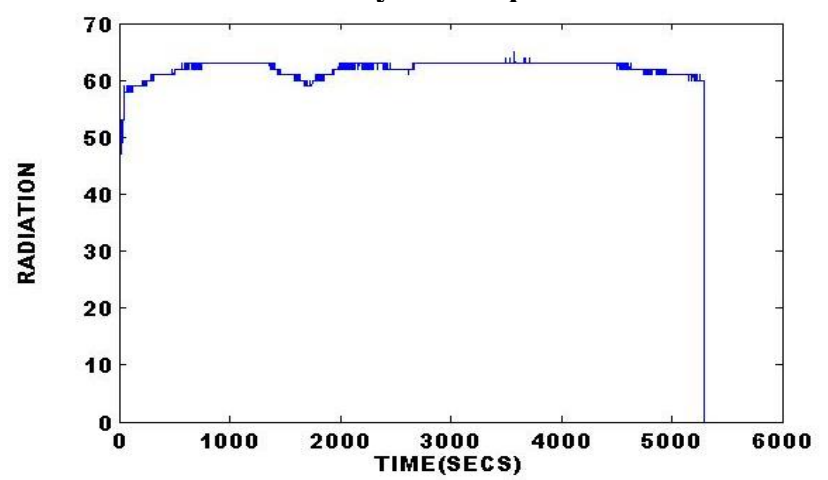

Figure 6: UV radiation(w/m²) against Time (sec) of Silver coated hibiscus extract in butanol solution for the polycrystalline panel.

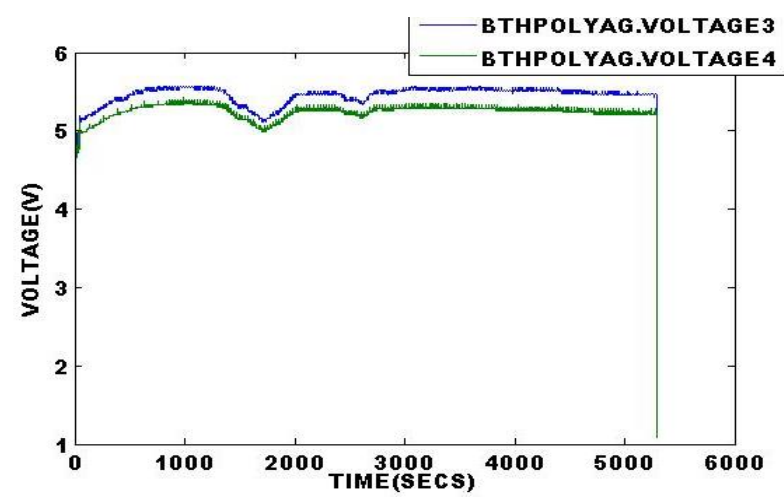

Figure 7: Voltage (V) against Time (Sec) of the Silver coated hibiscus extract in butanol solution for the polycrystalline panel.

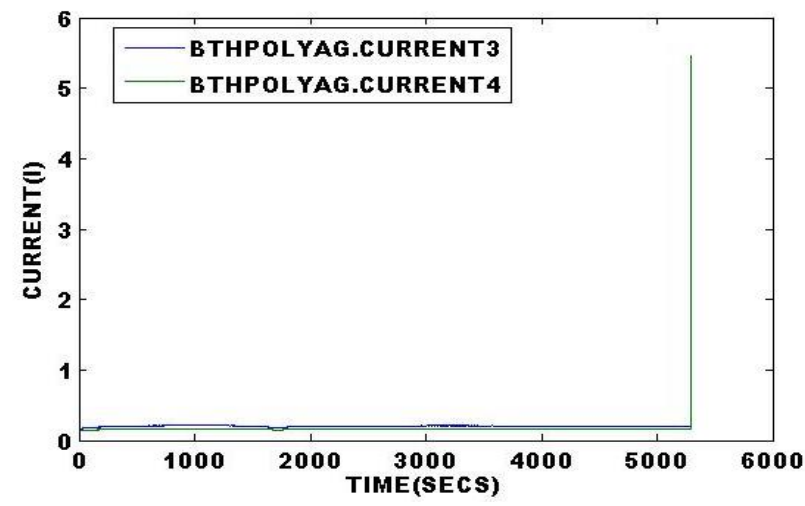

Figure 8: Current (A) against Time (Sec) of the Silver coated hibiscus extract in butanol solution for the polycrystalline panel.

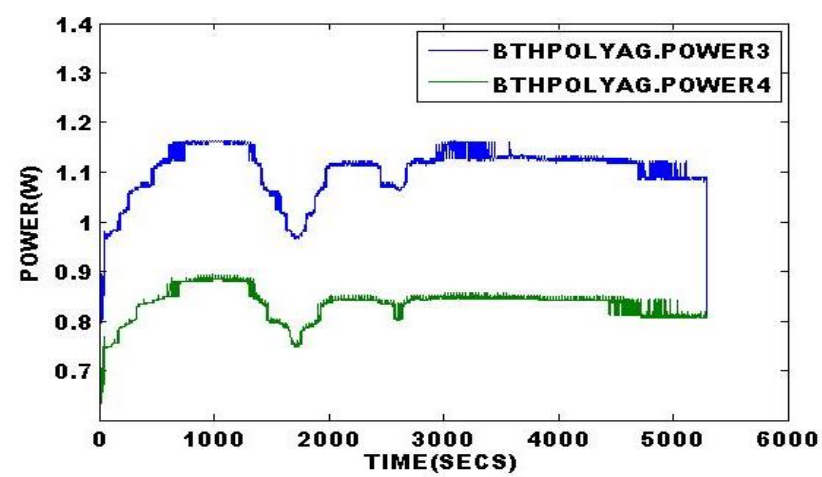

Figure 9: Power (W) against Time (Sec) of the Silver coated hibiscus extract in butanol solution for the polycrystalline panel

\section{CONCLUSION}

From the performance of the bio-filter on the monocrystalline and polycrystalline PV panel, it can be inferred that the silver coated hibiscus plant extract have high reflective properties to remove solar IR radiation. It was observed that the bio-filter improved the efficiency of the polycrystalline panel by $60 \%$. This means that a good percentage of the solar IR radiation can be reflected from this proposed bio-filter. 
This research further affirms the significance of plants as a veritable tool to protect the PV panel. Hence, this bio-filter is adjuged to be cost-effective (i.e. affordable), universal usability and eco-friendly in both the long and short term.

\section{ACKNOWLEDGMENT}

The authors wish to appreciate Covenant University for partial sponsorship.

\section{REFERENCES}

1. Labouret, A.; Villoz, M.; Énergie Solaire Photovoltaïque, 5th ed.; Dunod: Paris, France, 2010 ; ISBN 978-2-10- 055598-7.

2. Vandeligt, K.; Sophie, P.; Yves, P. Assessment of the Environmental Performance of Solar Photovoltaic Technologies; Environment Canada: Ottawa, ON, Canada, 2012; pp. 1-71.

3. Madeti, S.R.; Singh, S.N. Monitoring system for photovoltaic plants: A review. Renew. Sustain. Energy Rev. 2016, 67, 1180-1207, doi:10.1016/j.rser.2016.09.088.

4. Peled, A.; Appelbaum, J. Minimizing the current mismatch resulting from different locations of solar cells within a PV module by proposing new interconnections. Solar Energy 2016, 135, 840-847, doi:10.1016/j.solener.2016.06.016.

5. Duke, R.D., Jacobson, A., \& Kammen, D. M., (2002). Photovoltaic module quality in the Kenyan solar home systems market. Energy Policy 30(6), 477-99

6. Kafiul Islam, Tanvir Ahammad, Enamul Haq Pathan, A N M Mushfiqul Haque and Rezwanul Haque Khandokar, (2011), Analysis of Maximum Possible Utilization of Solar Radiation on a Solar Photovoltaic Cell with a Proposed Model, International Journal of Modeling and Optimization, 1(1): 66-69

7. Daure, S., Mittelstadt, L., Metz, A. \& Hezel, R. (2002), Progress in photovoltaics: Research and Application, 10: 271

8. PVeducation, (2019), Module Circuit Design, https://www.pveducation.org/pvcdrom/modules-and-arrays/module-ci rcuit-design (accessed 13/08/2019)

9. VM Andreev, (2003), GaAs and High-Efficiency Space Cells, in "Practical handbook of photovoltaics: fundamentals and applications", Eds. T. Markvart and Luis Castañer, Elsevier,

10. The Statistics Portal. Solar PV-Statistics \& Facts|Statista. The Statistics Portal. Available online: https:// www.statista.com/statistics/275932/world-construction-of-photovoltai c-systems-by-installed-capacity/ (accessed on 13 August, 2019)

11. Ariyo, F.; Famutimi, B.; Olowu, T.; Akintade, S.; Abbas, A. Web-Based Application for the Sizing of a Photovolatic (PV) Solar Power System. American J. Eng. Res. (AJER) 2016, 5, 219-222.

12. Mekonnen, Y.; Sarwat, A.I. Renewable energy supported microgrid in rural electrification of Sub-Saharan Africa. In Proceedings of the 2017 IEEE PES PowerAfrica, Accra, Ghana, 27-30 June 2017; pp. 595-599.

13. Carlos Campillo, Rafael Fortes and Maria del Henar Prieto (2012). Solar Radiation Effect on Crop Production,Solar Radiation, Prof. Elisha B. Babatunde (Ed.), ISBN: 978-953-51-0384-4, InTech, Available

from:http://www.intechopen.com/books/solar-radiation/solar-radiatio n-effect-on-crop-production (accessed on 13 August, 2019)

14. Brown R. D and Gillespie, (1995), Microclimate Landscape Design : Creating Thermal Comfort and Energy Efficiency, John Wiley \& Sons, New York.

15. Melecchi, M. I. S.; Martinez, M. M.; Abad, F. C.; Zini, P. P.; Filho, I. N.; Caramão, E. B.; Chemical composition of Hibiscus tiliaceus L. flowers: A study of extraction methods, J. Sep. Sci. 2002, 25, 86.

16. Lynn, P.A. Electricity from Sunlight: An Introduction to Photovoltaics; Wiley: Singapore, 2010; ISBN: 978-0-470- 74560-1.

\section{AUTHORS PROFILE}

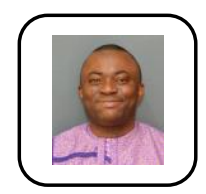

Emetere Moses is a seasoned researcher with significant awards and experiences. He has over 200 publications in highly rated, peer-reviewed journal.

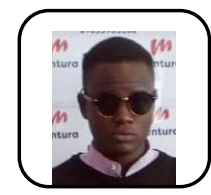

Adeyemo Nehemiah is a graduate of Industrial Physics-Renewable Energy option. 